\title{
Reforming WTO-Civil Society Engagement
}

\author{
ERIN HANNAH \\ King's University College at the University of Western Ontario \\ JAMES SCOTT \\ King's College London \\ RORDEN WILKINSON * \\ University of Sussex
}

\begin{abstract}
Civil society organizations are often seen as playing a crucial role in helping to mitigate the exclusion of weaker states, giving voice to marginalized communities, and raising environmental and developmental concerns within the trade system. The politicization and demystification of the global trade agenda by civil society also opens up space for a more diverse set of actors to influence trade negotiations. This article examines the evolution of the WTO secretariat's engagement with civil society within this context and argues that the dominant mode of engagement, as manifest in WTO Public Forums and civil society participation in ministerial conferences, is no longer fit for purpose. Rather it reflects an outmoded strategy that once served to underscore the existence and value of the WTO as an international organization and works to neutralize political contestation and publicly promote the benefits of free trade. It is now in need of reform.
\end{abstract}

\section{Reforming WTO-Civil society engagement}

Much of the recent commentary on the state of the multilateral trading system has focused on the lack of consensus among member states on how to reinvigorate the World Trade Organization's (WTO) negotiating pillar (see, for example, Hoekman, 2012; Deere-Birkbeck, 2011). This is unsurprising given the travails of the Doha negotiations and the decision to set the round aside at the organization's 10th ministerial conference in Nairobi in December 2015 (see Wilkinson et al., 2016). Yet, as WTO officials have been quick to remind us, behind the drama of the Doha round the non-negotiating aspects of the multilateral trading system have continued to function, and to do so well (see Azevêdo, 2015). The Dispute Settlement Body, though perhaps slightly overburdened, has been praised for dampening tensions between members that might otherwise have become headline events (Marceau, 2015). The Trade Policy Review Body has

* Email: rorden.wilkinson@sussex.ac.uk. 
continued monitoring member state compliance in a manner that has not caused major ripples. Aid for Trade is flowing to least developed countries (LDCs) and WTO members have pledged almost $\$ 90$ million to fund the second phase of the Enhanced Integrated Framework. The WTO's Economic Research and Statistics Division has contributed to enhancing the transparency of global trade flows as well as providing information that serves as a basis for inter-institutional coordination and analysis across the global trade landscape. And the WTO's Information and External Affairs Division has played a major role in abating the once hostile relationship between the organization and civil society.

However, the smooth functioning of the WTO's non-negotiating aspects has meant that they have not been subjected to the same kind of reform-orientated scrutiny as the system's negotiating function (see, among others, Meléndez-Ortiz et al., 2012; Warwick Commission, 2007; and Steger, 2009). Certainly, scholars and commentators have offered important suggestions for ironing out the creases in the dispute settlement and trade policy review processes (see, among many others, Hoekman, 2012; Georgiev and Van der Borght, 2006), but little beyond fine adjustment has been mooted. Very little has been said of the adjustments and reforms that could be made to the manner in which the WTO secretariat engages civil society. This is particularly pertinent given that - in contrast to other areas of WTO competence - no official review or reform process has been countenanced since a formal mode of engagement between the secretariat and civil society was first crafted. This does not mean, however, that reforming secretariat-civil society engagement has been entirely absent from the reform agenda. The 2013 Panel of WTO Experts report WTO at the Crossroads: A Report on the Imperative of a WTO Reform Agenda had engagement with civil society as the first of its recommendations calling for '[e]ach WTO Member [to] strive to undertake a national trade dialogue with their own respective citizens' (WTO, 2013: 31). It simply means that to date no concerted effort has been put into reforming and refining the means by which the WTO engages civil society.

There are good reasons to suggest that attention should now be turned to reviewing and reforming the manner in which the secretariat engages civil society. It is certainly the case that few, beyond a small hard core, now choose to demonstrate during WTO ministerial conferences; the proportion and the character of nongovernmental organizations (NGOs) present during the organization's annual Public Forum has changed; and the way the secretariat engages non-state actors has evolved and matured. All of this has been helped by a shift in the focus of public debate about trade towards mega-regional trade agreements such as the Transatlantic Trade and Investment Partnership (TTIP) and the Trans-Pacific Partnership (TPP) as well as the tectonic geopolitical, geoeconomic, and geostrategic movements that have occurred in wider world politics (see, for instance, de Ville and Siles-Brügge, 2015).

It is also the case that the manner in which the WTO engages civil society has been too narrowly focused on institutional needs and outcomes, rather than on 
more wide-ranging objectives. This is perhaps unsurprising, but it has ensured that the WTO is out of step with those other international organizations that have sought to deepen and widen their engagement with public stakeholders (see Scholte, 2012); and it has put the WTO behind the curve in harnessing the role that civil society can play in setting agendas, shaping the way issues are understood, implementing and operationalizing global norms (Friedman et al., 2005), and enhancing transparency, legitimacy, and accountability (Buntaine, 2015). As such, secretariat-civil society engagement is in need of the same kind of reformfocused reflection that has been directed towards the rest of the multilateral trading system.

Our purpose in this paper is to illustrate how, in its current form, the secretariat's engagement with civil society inhibits that relationship from utilizing the positive contributions that opening up the organization to greater public engagement and scrutiny can bring. We argue that currently constructed secretariat-civil society engagement remains largely focused on a public relations strategy that was originally designed to underscore the existence and value of the WTO as an international organization at a time when its purpose had been called into question. While this may have been important at the time, it does not serve a more general purpose of facilitating constructive dialogue about trade, the WTO, and civil society, which, in turn, has the capacity to bring about more transformative outcomes by which we mean a broadening of dialogue and debate; the introduction of alternative ideas, norms, and discourses; the inclusion of otherwise marginalized voices; and the consideration of progressive social values about human health, welfare, and sustainable development. More meaningful and critical engagement with civil society - particularly with progressive NGOs and social movements - has the potential to transform fundamentally thinking about the way global trade can lift people out of poverty and serve development priorities. Moreover, giving space to critical voices for developing counter-narratives that push against the boundaries of conventional wisdom can serve to unsettle the underlying power dynamics of global trade. Such transformative outcomes are needed if we are to develop trade policies that serve better the needs and priorities of the world's poorest people. Progressive NGOs and social movements are the best candidates for bringing about this type of transformative change.

We argue that the dominant secretariat-civil society mode of engagement, manifest most obviously through the organization and arrangement of the Public Forum and NGO attendance at ministerial conferences, is the consequence of an evolutionary process that reflects the aims and objectives of an earlier time and an outmoded but nonetheless enduring perception of what the value of civil society is to the WTO (members and secretariat alike) rather than the other way around. This mode of engagement is no longer tenable and it is now in need of reform.

We draw our argument from three sources of data. First, we draw from an extensive programme of participant observation at ministerial conferences since 2003 and Public Forums since 2010 that have provided us with the opportunity for 
innumerable informal discussions with participants from civil society about their engagement with the WTO. Second, we have compiled and utilized an original dataset of all civil society organizations registered at WTO ministerial conferences from 1999 to 2015 and Public Forums from 2002 to 2014, made available to us by the WTO secretariat for use in this research. The dataset includes the organizational and country affiliations of each participant at the WTO Public Forums and ministerial conferences. Each entry was coded as 'state', 'NGO', 'Labour', 'Business', or 'Academic'. The Public Forum data also include 'individuals' and intergovernmental organizations (IGOs). Each organization is also coded according to their socio-economic classification as either global North or global South. This was determined through a combination of Human Development Index rankings and geography. The data are used to detail the changing dynamics of participation in these events and the evolving patterns of attendance by different types of civil society organizations. Third, we have conducted more than 100 formal, informal, and semi-structured interviews with civil society groups, secretariat staff, and WTO member delegates for the period 2003 to the present day. Taken together, these data sources provide a comprehensive picture of the changing dynamics of WTO-civil society relations.

In developing our argument, the paper unfolds as follows. It begins by defining our terms and mapping out the changed nature of the civil society with which the secretariat engages. The paper then turns to the changed purposes that underpin the secretariat's engagement with civil society as well as the enduring character of the mode of engagement that was put in place more than 15 years ago. Thereafter, the paper explores the impossibility of broader, transformative social outcomes emerging from the mode of engagement's current construction. The paper concludes by reflecting upon the possibilities that a changed mode of engagement might hold.

\section{The changed nature of civil society at the WTO}

By WTO-civil society engagement, we are concerned primarily with relations between the secretariat and civil society rather than the WTO as a collection of members - though the latter are not unimportant, particularly as it is upon the mandate given by member states that the secretariat is able to act. In this regard, we are concerned with the secretariat not simply as a servant of the membership as it is often constructed, but also as an agent acting upon the authority bestowed upon it by the membership. We take civil society to be private individuals and representatives of non-state groups, including NGOs, labour (organized and unorganized), academics, business associations, and consumer organizations. More often than not, in the context of the WTO, civil society is taken to be NGOs alone, but this is only for convenience of mind and needs to be treated with caution. Equally, we need to be a little wary of the term 'public'. In everyday usage, the term public is often treated synonymously with civil society. However, in 
the WTO context, public is understood more in the sense of openness - hence it is a mistake to assume that we can draw a simple association between civil society and NGOs engaging with the WTO and a more wide ranging public engagement programme. The WTO's broad approach to what constitutes public engagement is problematic in itself, as by including a greater range of actors - such as for-profit corporations - the space for civil society groups, particularly those with transformative agendas, has been increasingly crowded out. It is, nonetheless, an important point to note in terms of the evolution of the primary manifestation of the means by which the WTO engages with civil society - that is, via the Public Forum and ministerial conferences.

The context of WTO-civil society engagement has changed dramatically since the demonstrations that first accompanied the 1998 ministerial conference in Geneva. Those events, and the on-the-streets public protests that followed during the Seattle (1999), Cancún (2003), and Hong Kong (2005) ministerial conferences - not to forget the smaller demonstrations that took place inside these events and which would often get NGOs banned from attending press briefings during ministerial conferences - are now rare (see Wilkinson, 2003; Hopewell, 2015; Pianta, 2014). The last time a ministerial conference was held in Geneva in 2011, for instance, the only lasting demonstration was an unstaffed tent opposite the conference centre decked out in a few bedraggled banners. In Bali in 2013, the handful of demonstrations that took place were far removed from the conference centre and out of the sight of member delegations. Demonstrations in Nairobi in December 2015 were limited to a small number of equally insignificant activities: a handful of protests involving no more than 25 people greeted ministers as they exited the conference centre each day; in the streets surrounding the conference South Korean farmers denounced the WTO and hand-written proclamations stating that 'trade is war' were scattered among the tents of the NGO centre drawing from the recent book of the same name by Yash Tandon (2015); and the NGO coalition Our World Is Not For Sale held regular court with the press and social media as well as with Kenyan-based NGOs.

More generally, the number of civil society organizations registering to attend ministerial conferences, as well as those actually attending, has fallen to such an extent that some of the most significant groups have declared that ministerial conferences are no longer sufficiently important to warrant the sending of a delegation (as Oxfam decided ahead of the Bali conference - see Benicchio, 2013). Such is the decline that the number of organizations attending has fallen from a high of 960 in Cancún in 2003 to a low of 232 in Nairobi in 2015 (see Figure 1).

Overall, two distinct periods can be identified - high numbers of civil society organizations registering to attend ministerial meetings in the run-up to and during the early stages of the Doha Development Agenda (DDA) negotiations when a deal looked most likely to be agreed (that is, up until July 2008), followed by subsequent disengagement as the round became increasingly moribund. The Doha (November 2001) ministerial conference is an obvious outlier in this trend. 
The relatively low levels of attendees in Qatar is explained by the restrictions placed on civil society activity and limited possibility of protest, and by the fact that the conference took place shortly after the attacks of 11 September 2001 at which point many chose not to travel by air. The stark decline in civil society attendance at, and engagement with, WTO ministerial conferences across all categories has reinforced the centrality of the Public Forum as the primary mode of engagement between civil society groups and the WTO with attendance at the Forum - in aggregate numbers at least - proving more robust.

Things have changed at the Public Forum as well, though in less obvious ways. Official statistics - shared with us by the WTO secretariat - show that the total number of participants at each Forum across the event's life span has remained remarkably constant, albeit with notable peaks in 2005, 2007, and 2011 (see Figure 2). However, what these figures hide are the changes that have occurred in the character of attendees. The complexion of the communities represented has shifted away from activist groups and NGOs to those representing economic interests. Indeed, it is significant that among those registering to attend the Public Forum are both non-profit business associations such as the Canadian Hatching Egg Producers and for-profit corporations such as AT\&T and Daimler Chrysler, which do not fit neatly with common understandings of what are considered to be constituents of civil society. Registration by a number of IGOs and statebased representatives, such as those working in permanent missions to the WTO, also inflates the number of participants at the Public Forum. Indeed, the combined number of state and IGO representatives registering for the Public Forum obscures what is in reality a year-on-year decline in civil society participation.

It is also worth noting that the figures presented below relate to the total number of registered participants rather than the number that actually attended. The only year for which data are available in this respect is 2006, when two-thirds of registrants are reported by the WTO to have attended. ${ }^{1}$ It is also important to note that the reported figures do not record the sessions that participants attend during the Forum: a significant proportion of delegates from the Geneva diplomatic community attend plenary sessions and a few other select panels only. They are not present for the event in its entirety or many of the other sessions. This, in turn, ensures that plenary sessions are busy and makes the Public Forum appear well attended.

How marked have these shifts really been? As Figure 3 shows, since 2010 business groups (comprising for-profit industry representatives as well as not-for-profit business associations) have contributed the most participants, reversing the preceding norm wherein NGOs were typically the largest group. In 2013, business

1 According to the WTO with respect to the 2006 Public Forum: 'A total of 1,396 persons registered to participate in this year's Forum (see chart for breakdown by category of registered participants) and 136 additional people were registered manually after the expiry date of the on-line registration. Approximately 1,000 participants actually attended the event.' See: https://www.wto.org/english/forums_e/public_for um_e/forum06_e.htm 
Figure 1. Civil society organizations registering to attend ministerial conferences, 1999-2015

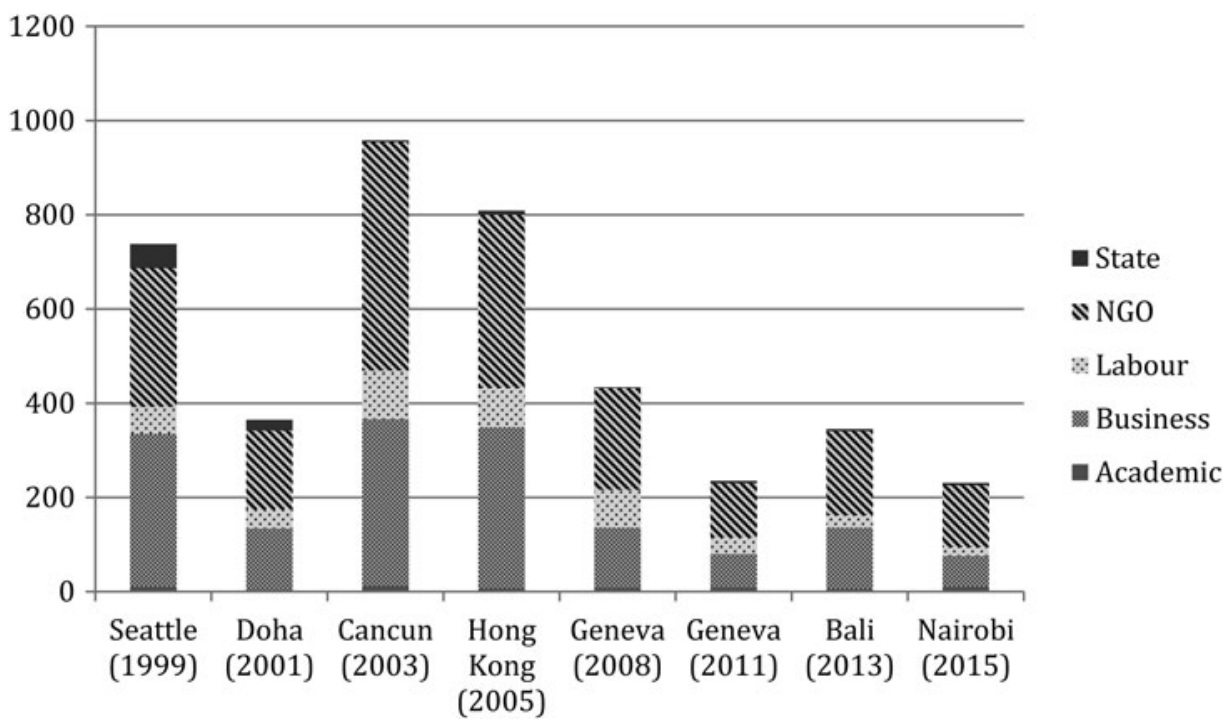

registered fully $55 \%$ more delegates than NGOs, though this subsequently fell back to $27 \%$ more in 2014 . NGOs now typically make up the fourth largest group of participants, having also been overtaken by state representatives and representatives of universities and high schools. Representation from other potentially more critical civil society groups has also fallen back. For instance, attendance by labour groups reached a peak of $4 \%$ of the total participants in 2005 before falling back to around $1 \%$ after 2008 .

When combined, business, state and IGO representatives make up approximately half of the audience at Public Forums. If Public Forum attendance can be taken as a crude proxy measure, business interest in the multilateral trading system (and perhaps the networking opportunities that the Forum affords) is actually more pronounced than has been suggested (consider, for instance, Woll, 2013: 258). Importantly, civil society - private, non-state, not-for-profit groups - has over time become a less important constituency at the Public Forum, which might be a trend worth reversing if secretariat-civil society engagement is to have any continuing value.

The WTO provides another entry point for NGOs working on trade-related issues in addition to the Public Forum and the sidelines of ministerial conferences. Geneva-based organizations can apply for accreditation to the secretariat, receive regular briefings from the secretariat, and attend public hearings of some of the WTO dispute settlement proceedings. The issuing of badges is meant to facilitate 
Figure 2. Public Forum participants, 2002-2014

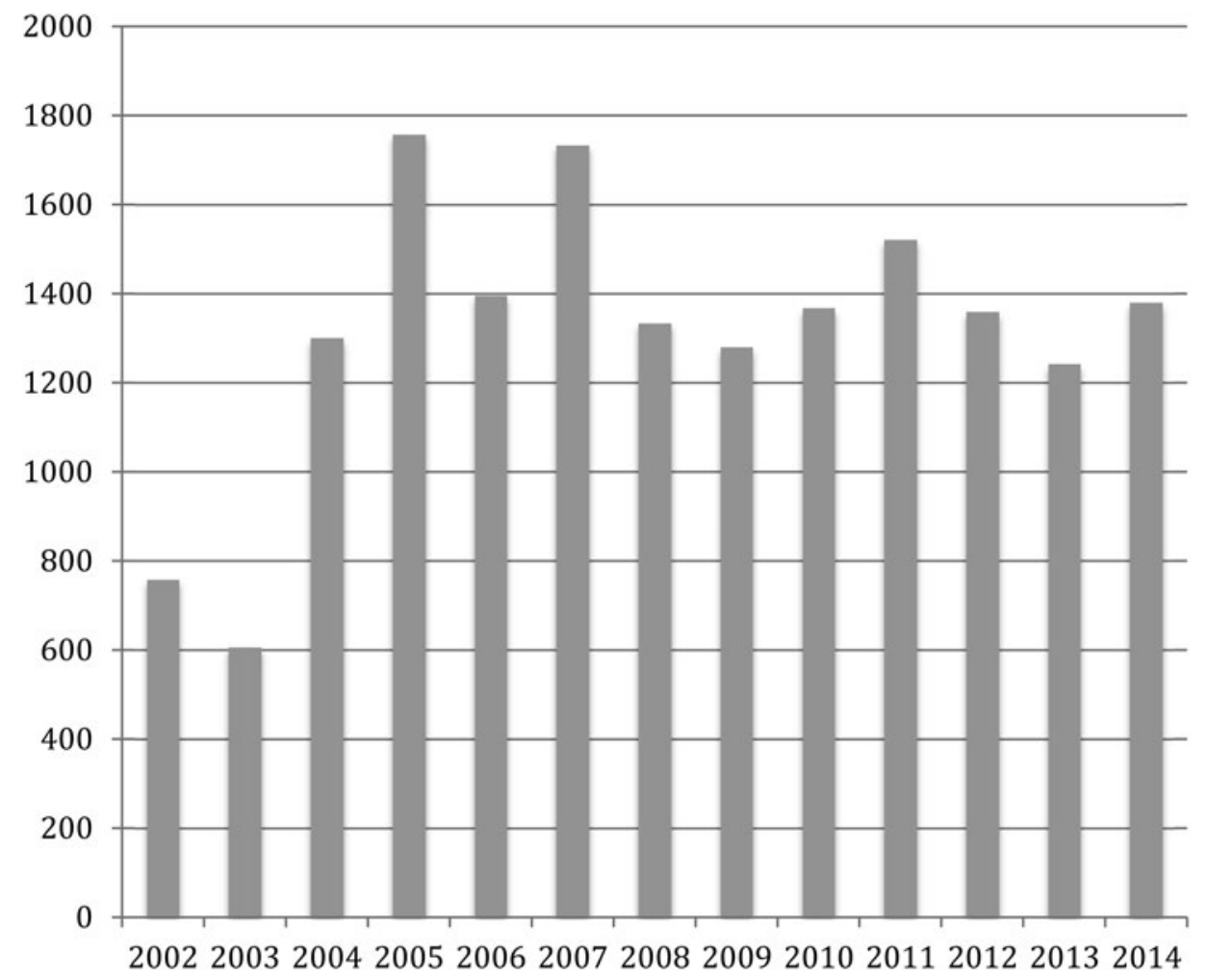

the entry of NGOs to the Centre William Rappard building. Currently 52 Genevabased NGO representatives hold such badges. ${ }^{2}$

That said, it remains the case that when attendance at the Public Forum is scrutinized closely we see that the character of civil society engagement with the WTO has changed considerably. Public expressions of disaffection with the trade agenda have almost disappeared from ministerial conferences and Public Forums alike. The consequence is that secretariat-civil society relations have been boiled down to a whisper of protest at ministerial conferences and a Public Forum that is dominated by noncivil society actors. And because of the composition of the delegates in attendance at both events, this inevitably ensures that a certain character is lent to the meetings how they are run, what is talked about, what kind of interaction takes place.

Given that the dominant view of the majority of these attendees is generally status quo/WTO supporting, the space for alternative views is limited. This

2 See 'NGOs and the WTO' - https://www.wto.org/english/forums_e/ngo_e/ngo_e.htm. 
Figure 3. Public Forum participants by category, 2002-2014

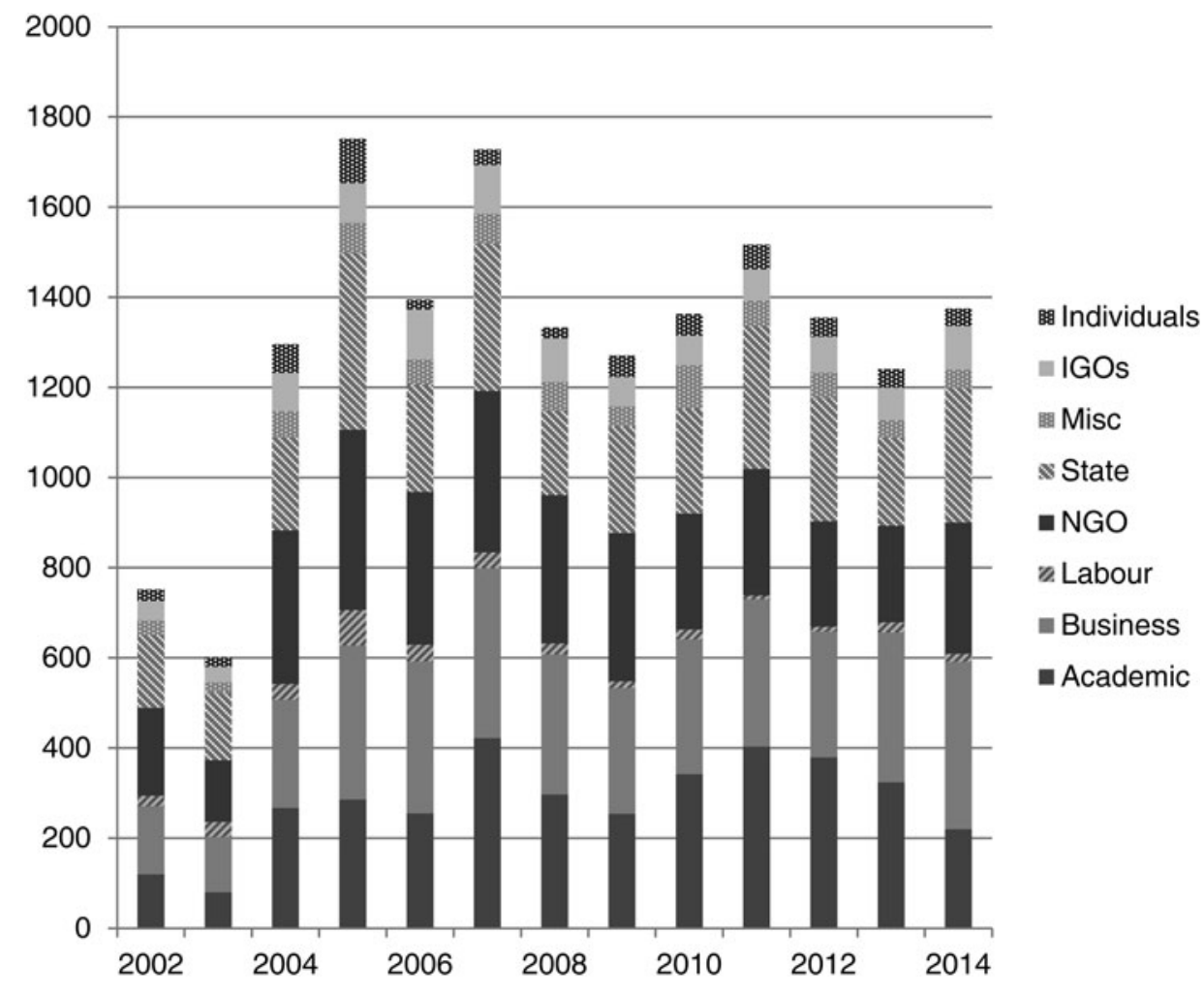

development is perhaps best illustrated by the themes of Public Forum panels. The Secretariat selects panels from the pool that has been proposed by participants (the complexion of which, as we have outlined, is increasingly dominated by business, state, and IGO representatives), based on the quality of proposed speakers, range of voices, and 'fit' with the overall theme of the Forum. The large majority of these sessions focus on the technicalities associated with enhancing the functioning of the multilateral trade system - implementation, rules compliance and dispute settlement, competitiveness, global value chains, jobs growth, technical innovation and celebrating the benefits of freer trade. Very few are concerned with challenging prevailing orthodoxies or providing meaningful opportunities to engage in critical discussions about the more iniquitous aspects of global trade governance. ${ }^{3}$ Since participants put the panels forward they may give an indication of the issues that

3 Public Forum programmes are available through: https:/www.wto.org/english/forums_e/public_for um_e/public_forum_e.htm 
key groups wish to discuss, but because of the selection process by the Secretariat, this view cannot be taken as representative. Moreover, because of the selectivity, participants may self-censor in what they propose.

Clearly, there are important corollaries here - such as why civil society interest in the WTO has fallen so dramatically. Without doubt, a component of the explanation of NGO disengagement with the WTO lies with the lack of progress in the Doha round. For civil society groups facing resource constraints and operating on a model of pursuing a small number of key campaign areas at any one time, once the WTO negotiations showed little sign of moving beyond the 2008 impasse their attention was bound to turn elsewhere - to the global financial crisis, the inclusion of Investor State Dispute Settlement mechanisms in megaregional agreements, and to sustainable development and poverty alleviation more generally. NGO engagement with the Public Forum was fairly steady throughout the early years of the Doha negotiations, with a particular peak in 2005 coinciding with the highly politicized Hong Kong ministerial conference (Wilkinson, 2006). This engagement was maintained through to the 2009 Public Forum, at which the topic under discussion- 'Global Problems, Global Solutions: Towards Better Global Governance'-was one that encouraged greater input from NGOs pushing for change in the trade system and maintained their interest. The year 2010, however, saw a fall of $22 \%$ in the number of NGOs registering to attend, and set in motion a new period of significantly lower engagement by NGOs with the Public Forum as many moved on to new campaign areas.

This disengagement by civil society has the result of narrowing the range of voices heard at the event and reducing the set of ideas that are put forward in response to the questions posed by the Public Forum. The space in which civil society engages with the multilateral trade system has contracted considerably, leaving the discussion as one primarily conducted between the state, IGOs, and business representatives. It is not, however, just the character of civil society attending WTO events that has changed over time and which requires attention in any process of reform. So too have the underlying purposes - but importantly not the methods - of the secretariat's engagement with civil society. It is to the issue of changed purpose but continuity of method that we now turn.

\section{The changed purposes that underpin the secretariat's enduring engagement with civil society}

Despite the changes that we observe in the composition and behaviour of civil society at Public Forums and ministerial conferences, the way the secretariat engages civil society has not changed markedly at all. It remains largely unidirectional, constructed to 'educate' and 'celebrate' the benefits of trade, leaving unaltered the mechanisms governing WTO-civil society engagement. That said, there has been a change in the purposes underpinning that engagement that has 
resulted from the changed circumstances in which the WTO has found itself. It is important to understand why this combination of continuity in machinery but change in purpose has come about, as well as the effects on secretariat-civil society relations. To do this, we need to recount briefly the genesis and evolution of WTO-civil society engagement.

The events of Geneva in 1998 and (infamously) Seattle in 1999 set in motion an institutional strategy designed to engage civil society that sought, simultaneously, to:

1. promote public understanding of the benefits of trade;

2. dissipate civil society hostility towards the WTO and the multilateral trade agenda; and

3. preserve an arm's length relationship between members and civil society groups.

What resulted was a mode of engagement that privileged a uni-directional flow of information about the benefits of trade and the WTO from the secretariat to civil society but which had very little in the way of a feedback mechanism. As the DDA became ever-more intractable - and more generally interest in global economic issues dissipated - the reasons for persisting with this mode of engagement shifted towards underpinning the continued relevance (indeed, the indispensability) of the WTO in the face of challenges that threatened to encourage a contrary view (for statements from WTO Directors General concerning threats to the organization, see WTO, 2012, 2014). In this way, a shift occurred from a mode of engagement designed to dissipate civil society hostility to one that sought to shore up and justify the WTO's raison d'etre. Yet, while the underlying reasons may have changed, the mode of engagement did not. We explore each of these phases in turn.

In the first phase, the secretariat sought to keep public interest in the WTO and its work at arm's length, with the responsibility for civil society engagement in WTO and related affairs firmly placed with member states, resisting the movement of non-state actors to lobby the WTO directly (Scholte et al., 1998). As early as 1996, the General Council agreed a set of 'Guidelines for Arrangements on Relations with Non-Governmental Organizations' (WTO, 1996), which set out the 'broadly held view' of precluding NGOs from any direct involvement in the work of the WTO or its meetings, and highlighting the importance of consultation at the national level, "where lies primary responsibility for taking into account the different elements of public interest which are brought to bear on trade policymaking' (WTO, 1996; also Wilkinson, 2005). The WTO's attempt to manage civil society relations while continuing to insulate itself from non-state input was also visible in the creation of the Public Forum (initially established as the Public Symposium) wherein civil society representatives could engage with the organization but they could do so only away from-geographically as well as time-wise - the organization's primary decision-making body, the ministerial conference. It was no coincidence that the first Public Forum was held in July 2001 in the wake of the inflammatory 1999 Seattle ministerial conference and in the run-up 
to the November 2001 Doha ministerial meeting (at which the Doha round was launched). This public engagement strategy was complemented by the rolling out of an education programme which comprised the production of a series of information guides on the work of the WTO, as well as a huge investment in, and up-scaling of, the organization's website to correct what the secretariat saw as a number of errors in public perceptions about the institution and its work. The most notable of these was the ' 10 Common Misunderstandings about the WTO' (WTO, 1999) which has subsequently morphed into ' 10 Things the WTO Can Do' (WTO, no date).

In the years running up to the turn of the millennium, the extent of public illfeeling toward the global trade agenda caught the secretariat very much on the back foot and the production of early information documents like ' 10 common misunderstandings ...' reflected a knee-jerk and defensive response on the organization's part, as did the attempt to deflect criticism from itself and towards member states as the 'appropriate' venue for raising issues of concern. This was, however, to change. If the secretariat's first response was defensive and 'educational' (in that it sought to combat criticism by disseminating its own ideas about what it is that the WTO is and does), it soon morphed into a mode of engagement principally about political neutralization. This change in policy has been most evident during ministerial conferences as well as during Public Forums but it has also been manifest in a shift in the language of publically available documents and the way the institution now presents itself virtually (a shift that the move from ' 10 common misunderstandings ...' to ' 10 things the WTO can do' illustrates).

In seeking to defuse some of the political tension around meetings, the secretariat has had some success. With regard to ministerial conferences, the secretariat has been able to meet the obligation of hosting these meetings while at the same time divorcing them from the 'heat' of the negotiations and the ire of some quarters of civil society. This was the case at both the 2009 and 2011 Geneva ministerial conferences as well as - less expectedly so - at the 2013 Bali and 2015 Nairobi meetings (which, as we noted above, were both sparsely attended by representatives of civil society). As Scott and Wilkinson (2010) noted with regard to the 2009 Geneva conference:

In sharp contrast to its previous ministerial gatherings, the World Trade Organization's 7th ministerial conference in Geneva (30 November to 2 December 2009) proved to be something of a success. This was perhaps not surprising. The meeting was actively engineered from the outset to be a 'non-event', an institutional stocktaking exercise, and a routine gathering rather than an ambitious negotiating session attracting large scale demonstrations and political grandstanding among the delegates.

Scott and Wilkinson continued,

[T] he meeting's only real 'success' was that it was hosted in such a way that enabled some of the political heat to be taken out of WTO ministerial conferences 
moving the institution back to a more technocratic pace. This was precisely because, as Faizel Ismail, Head of the South African Delegation, put it, 'there is zero going on', a lack of industry (particularly with regard to the Doha round) which Alan Beattie likened to 'the rough equivalent of holding the 1919 Versailles conference without talking about the war'. (Beattie, 2009)

This strategy of neutralization has also been evident in WTO Public Forums (listed in Table 1). As noted above, a distinct shift has occurred in the nature of Public Forums, moving them away from venues in which civil society could be educated about the WTO and a place for public engagement with the organization, to a politically neutral venue populated less by 'the public' and more by representatives of business and the legal and diplomatic professions taking advantage of the networking opportunities such gatherings now afford. At the 2013 Public Forum, for example, almost none of the major civil society players chose to put forward panel proposals for the sessions available. The second of the two plenary sessions was led by a particle physicist (Rolf-Dieter Heuer, Director General of the Conseil Européen pour la Recherche Nucléaire) who, by his own admission, had little to say that was about trade (and, it should be noted, whose presentation had little connection with the rest of the session). Very few of the panels comprised anyone with a core role in the WTO or the Doha negotiations. And the topic of debate - 'expanding trade through digital innovation' - was hardly the best choice just two months prior to the crucial Bali Ministerial, as noted by ambassadors, delegates, and civil society representatives alike who openly expressed (in private conversations with us as well as in questions raised during panel sessions) their dissatisfaction and their intention not to attend in the future.

Irrespective of the problems with seeking to neutralize the debate, what this strategy did was to put in place a mode of engagement that was very much directed at policing the boundaries of debate about trade and the WTO. Moreover, as the reasons underpinning this mode of engagement have changed from one directed at neutralizing civil society hostility to one that pushes back against suggestions that the value of the WTO has been undermined by the lack of progress in the Doha round, a further consolidation of the secretariat's strategy has unfolded. This comprises the establishment of ancillary functions and activities that are designed to lend the organization credibility independent of what happens in the negotiations. It includes, among other things, the significant up-scaling of the institution's data collection and analytical capacity, a joint initiative with the OECD to measure 'value-added in trade', and a significant increase in the number of working papers produced. The secretariat has also made extensive use of video and podcast technology, YouTube, and Twitter. It has established a 'chairs programme' of identifying and appointing university professors with the title of 'WTO Chair' (ostensibly aimed at supporting the developing world in its trade policy strategies) designed to build lasting relationships with the institutions involved by encouraging members to engage in outreach and communication activities and to establish links 
Table 1. WTO Public Forums and Symposia

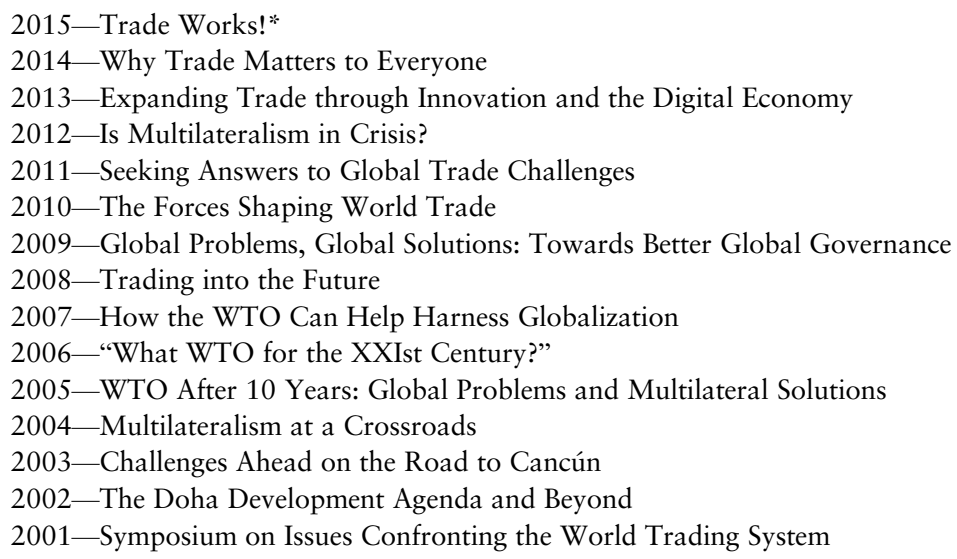

Note: "The exclamation mark appears not on the WTO's description of the forum but on the forum description on the dedicated website. Azevêdo suggested during the first plenary that a word was missing, that it should read 'Trade works if ...' which of course fundamentally changes the meaning. Source: https://www.wto.org/english/forums_e/public_forum15_e/public_forum15_e.htm.

with think tanks, but which actually has only appointed scholars uncritically disposed to the status quo.

In 2011, the WTO launched its Youth Ambassador Programme (YAP) ${ }^{4}$ designed to increase awareness of trade issues among younger people, to encourage their participation in public discussions on this theme, and to introduce new perspectives to debates - albeit that this has been targeted at disseminating the 'right' kind of knowledge rather than facilitating genuine debate. In 2009, the WTO Essay Award for Young Economists was introduced - and with it a CHF5000 prize to further promote links between academia and the WTO and "promote highquality research on trade policy and international trade co-operation'. As the list of award winners attests, this is an activity that is aimed at promoting trade orthodoxy rather than engaging with heterodox viewpoints. ${ }^{5}$

Across all of these activities, a strategy can be seen in which the secretariat seeks to encourage engagement with civil society that is narrowly focused. Whether it is the way it seeks to neutralize political contestation during ministerial conferences and Public Forums, or the selection of a winner from the YAP, the emphasis is on promoting the 'right' kind of knowledge about the WTO rather than stimulating critical thinking or engagement. And while this might be an entirely

4 Notably the programme was suspended indefinitely after the 2014 Public Forum.

5 See https://www.wto.org/english/news_e/news15_e/rese_04feb15_e.htm for that list. 
understandable strategy for a secretariat feeling the heavy weather of a stalled (and now, a set aside) Doha round, the consequence has been to preserve an increasingly outmoded way of engaging with civil society.

The result of all of this has been, first, to establish, then second, embed and consolidate an asymmetrical mode of engagement. Like all modes of engagement, as well as other institutional processes, once created they generate a life of their own. They establish a culture of operating that is learnt, carried forward, institutionalized, and seldom questioned. Perhaps now we need to stand back and ask questions about whether this mode of engagement is really appropriate or fit for purpose.

\section{The impossibility of broader social outcomes from the existing mode of engagement}

Why does any of this matter? It matters because this mode of engagement is deeply constraining and it has resulted in a dry, unquestioning forum wherein the raising of concerns about the appropriateness of where the global trade system is going are excluded. For example, by determining the substantive agenda of the primary meetings during which the secretariat and civil society engage (such as the theme for each Public Forum), debate can only ever be about particular issues; and while it may facilitate the airing of differences of opinion, inevitably there is an underlying objective to promote one way of thinking about global trade and the WTO. It is important to note here that to criticize what has gone on in the Doha round or to call into question some of the tactics that members use to strong arm others into accepting deals they might not otherwise have accepted is not to be antitrade, nor is it to be anti-WTO. It is certainly to raise questions about the kind of trade regulation that has prevailed over the past 70 years, which has seen the industrial states get more of the opportunities they already had while simply letting the rest scramble around for what they can get; but it is not against an organization that serves global commerce in a way that opens up opportunities to the excluded, which privileges capacity building in areas that have none (but in which potential exists), and it certainly is not a slight on the individuals who work in the secretariat.

The problem is that the mode of engagement that has developed between the secretariat and civil society is one that preserves the status quo and does not produce innovative thinking about the global trading system - some of which could actually contribute to its better and more effective functioning. As a result, nothing of substance, or of note, comes out of WTO Public Forums or of the organization's engagement with civil society at ministerial conferences. Contacts are made, networks are established, information is gathered, and familiar arguments are rehearsed. While this is not without some value, a dialogue of this sort fails to generate an outcome beyond the purposes for which secretariat-civil society engagement was first designed. What a sufficiently significant outcome might look like 
is beside the point for present purposes, not least because we make no claim to represent civil society or the range of views held therein. What matters is that the chances of a mode of engagement producing something it was not designed to elicit are slim, in much the same way that WTO negotiations currently configured are unlikely to produce outcomes that are equitable and beneficial to all members (Wilkinson, 2014).

\section{The possibilities that a changed mode of engagement holds}

Recent work concerning the influence of civil society on the WTO has drawn attention to the lack of success that coalitions of NGOs have had in either shaping or blocking the liberalization agenda (Pianta, 2014; He and Murphy, 2007) and how this has been manifest in a problematic mobilization against any form of multilateral trade agreement (de Bièvre, 2014). Yet, engagement between the WTO and civil society is often portrayed as an important element of making the global trade system more legitimate and democratically accountable (Williams, 2011; Piewitt, 2010; Steffek and Ehling, 2008; Higgott and Erman, 2010). In an early academic intervention on the relationship between civil society and the WTO, Scholte, O'Brien, and Williams (1998: 6-8) identified six benefits to the global trade regime of opening up to engaging with civil society, along with five potential problems if done badly. Since that time much has changed, but, as we argue above, the nature of the relationship has endured and the overall result amounts to a case of plus ça change, plus c'est la même chose. Many of Scholte et al.'s observations remain valid and point to continued potential. For instance, they note that civil society groups could act as an important stimulus of debate about trade policies by generating new perspectives and proposals as well as pushing the WTO to clarify and perhaps rethink its positions. Yet failing to engage with a representative group of civil society organizations would impede this benefit. In addition, they note the potential democratizing effects of greater engagement by citizens' groups in the WTO, and the pitfalls of alienating potential civic partners if engagement with civil society were treated merely as a public relations exercise (Scholte et al., 1998: 7).

Hannah (2016) also outlines several of the prospective benefits meaningful engagement with civil society could bring. The most obvious advantage is increased public awareness about the potential benefits and costs associated with liberalizing global trade, particularly for the world's poorest people. Yet, stimulating and improving the quality of public debate and deliberation about substantive trade policy issues, normative ideas about the egalitarian distribution of social goods, and the democratic quality of trade governance itself would also be a significant gain. Through meaningful engagement with civil society, the secretariat could widen policy debates and encourage the expression of multiple and critical views, even those that challenge prevailing trade orthodoxy. All too often, those who deviate from dominant ways of thinking are silenced and accused of not 
understanding sufficiently the trade system (Eagleton-Pierce, 2012; Hopewell, 2016; Howse, 2002; Wilkinson, 2014). Claims to expertise, exclusionary language, and entrenched metaphors serve to limit debate and police the boundaries of who can contribute to trade debates and who cannot (Hannah et al., 2015). Weakening these barriers could give rise to a third prospective benefit: giving voice and recognition to otherwise marginalized groups that have been silenced by decades of asymmetric and iniquitous trade deals. Improving the transparency of multilateral trade negotiations may also result if civil society has forums in which to monitor, scrutinize, and assess the development and impact of proposed trade policies. A fourth possible benefit is that civil society may also improve the accountability of trade negotiations by publicizing grievances or naming and shaming in public contexts (Hannah, 2014). Finally, meaningful engagement with the WTO might enable civil society to help convince trade policymakers to pursue policies aimed at producing welfare gains for all, safeguard public goods, and/or link trade rules up to progressive social values, human health, or sustainable development.

Nonetheless, it must be acknowledged that the secretariat's room for manoeuvre is currently limited because of its mandated relationship with WTO member states. The primary function of the secretariat is to serve the needs, interests, and priorities of WTO member states and to support their negotiating positions. More meaningful engagement with civil society would require that more autonomy be given to the secretariat in order to foster an environment where critical views are encouraged. A changed WTO secretariat-civil society relationship might ensure the rules better served the needs, interests, and priorities of a wider range of members, particularly the poorest among them.

The analysis above suggests that the mode of civil society engagement that the WTO has put into place has not made the most of the potential benefits and, simultaneously, not avoided all the pitfalls. While it is certainly understandable that a still nascent institution facing the kind of pressure precipitated by the events of Seattle in 1999 would seek to manage civil society engagement as a means of neutralizing criticism, that time is now over. It is time to step back and confront the reality that the WTO has generated a type of engagement with civil society that is no longer fit for purpose.

\section{Looking ahead}

What should be done? How can the secretariat generate opportunities for civil society to challenge meaningfully and transform conventional wisdom about global trade? Here are a few ideas - most of which relate to the Public Forum but which resonate for broader secretariat-civil society engagement, particularly at ministerial conferences.

First, the WTO should resist the temptation to define the terrain on which engagement with civil society takes place. At present, senior members of the 
secretariat, under the guidance of the Director General, agree on a topic for each Public Forum that determines in large measure the areas of debate to be explored. Each panel proposal has to specify how it is addressing that core theme, though this rule may not be followed entirely to the letter when panels are chosen for inclusion. Nonetheless, it inevitably constrains areas of debate.

Second, and relatedly, the WTO should take steps to allow civil society to have an input into the agenda-setting process, possibly through the creation of a consultative committee that brings together representatives of civil society broadly defined. Currently, panellists for the Public Forum propose topics that are adjudicated by secretariat staff, with roughly a $50 \%$ success rate, based on quality and congruence with the overarching theme of the event. Broadening the selection process would increase the legitimacy, accountability, and transparency of civil society outreach by the WTO and ensure that the topics being discussed reflected the areas of concern to civil society. Such an improvement in secretariat autonomy over the Public Forum would also require the DG to play a less decisive roll in setting the theme and an openness to themes that may not speak to the interests and priorities of the most dominant WTO members.

Third, the secretariat should allow a proverbial hundred flowers to bloom in the conversations that take place around trade. Too much effort is currently exerted in defending the benefits of trade and of the multilateral trade system to let genuine debate flourish. For instance, situating a debate around the topic 'Trade Works!' - as it was in 2015 - necessarily gives a certain direction and hue to discussions, and largely excludes those who are more critical. While it is reasonable for the WTO to maintain some level of oversight concerning which groups can attend, this should be kept to a minimum. Excluding such voices closes off fulsome debate and limits the possible outcomes of civil society engagement with the WTO.

Fourth, the secretariat should create opportunities for civil society to ask not what trade does, but what can trade do if we connect it up with a real development agenda that targets the poorest and least able, and that transfers knowledge that benefits everyone. This puts the secretariat in the role of enabler. By doing this, and not feeling the need to pursue dogmatically one understanding of trade, the system is better held to account. Furthermore, a foundry of ideas is crafted out of which could emerge proposals that genuinely challenge the normative foundations of the multilateral trading system and rouse it from the malaise in which it finds itself.

Fifth, we must be cognizant of the fact that the most critical elements of civil society and many of those who actively mobilized in opposition to the global trade agenda and the WTO in its early years have disappeared entirely from the scene. For example, Oxfam International, Third World Network, Médecins Sans Frontières, Aids Coalition to Unleash Power (Act Up), Greenpeace, ATTAC, Global Justice Now (formerly known as World Development Movement), 
ActionAid, and Friends of the Earth have all dramatically reduced (or even eliminated) their participation at Public Forums or ministerial conferences since 2005. They have lost interest in the WTO and the multilateral trading system and this points to a much broader challenge for secretariat-civil society relations. Reengaging critical elements of civil society will require the secretariat to re-imagine the purposes of public dialogues about global trade and broaden opportunities for debate such that it centres on issues that resonate beyond the WTO and the Doha round. This will take much creative energy on the part of the secretariat and can only be achieved in consultation with civil society itself. Hosting civil society events organized around crosscutting issues related to mega-regional trade agreements, poverty alleviation, debt, and finance, and sustainable development, among others, is one way to begin.

Sixth, the secretariat must make a stronger effort to engage civil society from the global South in Public Forums and ministerial conferences. Although the External Relations unit does a good deal in terms of in-country and regional outreach for civil society (and media), providing opportunities for private, non-state, not-forprofit actors to engage in debate and dialogue with their counterparts from around the world will enrich and balance discussions about the possibilities of trade to work for global development and produce welfare gains for all. As Hannah (2014) argues:

NGOs from the North, in particular, are directed by Western-educated, middle class people who speak from a position of privilege. This raises questions about the appropriateness of NGOs claiming to give voice to the poor and marginalized in international trade negotiations, and raises the risk that NGOs may serve to reproduce social hierarchies or inequalities in the global economy. ${ }^{6}$

If the transformative potential of civil society is to be realized and engagement with the WTO is to be fit for purpose, voices from the South must be included.

So, the terms of engagement with civil society should not simply reflect what the secretariat thinks and wants. They should be determined in consultation with others beyond the doors of the WTO. For selecting the topics of the Public Forum in particular, there should be a committee that has a range of constituents on board that cover the whole spectrum of opinion so that they are all forced into a dialogue. Whatever it produces, it will be more democratic, accountable, legitimate, and transparent than before. It may even produce something genuinely progressive and transformative - an outcome that pushes back against conventional wisdom while generating new ideas geared towards health, welfare, and sustainable development priorities. 


\section{Acknowledgements}

We gratefully acknowledge the support of the Social Sciences and Humanities Research Council of Canada for funding part of the research out of which this paper emerges. We are grateful to those members of the WTO Secretariat - particularly Anoush der Boghossian and Bernard Kuiten - who helped us compile data for this project and who shared their time and insight with us freely as well as to the great number of people with whom we have engaged on issues of WTO civil society reform over the last 15 years. We are also grateful to Silke Trommer and Amy Wood for their input in helping craft the ideas contained herein as well as to L. Alan Winters and the two anonymous reviewers whose suggestions helped strengthen both the text and the argument. Responsibility for any errors nonetheless resides with us.

\section{References}

Azevêdo, R. (2015), 'MC10 Opening Ceremony', Speech by Director-General Roberto Azevêdo', 15 December, https://www.wto.org/english/news_e/spra_e/spra103_e.htm, (accessed 17 December 2015).

Beattie, A. (2009), 'Retread Required', Financial Times, Asia edition, 1 December, p.7.

Beauzamy, B. (2010), 'Transnational Social Movements and Democratic Legitimacy', in E. Erman and A. Uhlin (eds.), Legitimacy Beyond the State? Re-examining the Democratic Credentials of Transnational Actors, Basingstoke: Palgrave.

Benicchio, R. (2013), 'The WTO Tries to Prove It Is Relevant, but to Whom?', 2 December 2013, http:/ politicsofpoverty.oxfamamerica.org/2013/12/not-dead-yet-the-wto-tries-to-prove-it-is-relevant-butfor-whom/ (accessed 27 October 2015).

Brühl, T. (2010), Representing the People? NGOs in International Negotiations', in J. Steffek and K. Hahn (eds.), Evaluating Transnational NGOs: Legitimacy, Accountability, Representation, Basingstoke: Palgrave.

Buntaine, M. T. (2015), 'Accountability in Global Governance: Civil Society Claims for Environmental Performance at the World Bank', International Studies Quarterly, 59(1): 99-111.

de Bièvre, D. (2014), ‘A Glass Quite Empty: Issue Groups' Influence in the Global Trade Regime', Global Policy, 5(2): 222-228.

Deere-Birbeck, C. (2011), Making Global Trade Governance Work for Development: Perspectives and Priorities from Developing Countries, Cambridge: Cambridge University Press.

de Ville, F. and Siles-Brügge, G. (2015), TTIP: The Truth about the Transatlantic Trade and Investment Partnership, Cambridge: Polity Press.

Eagleton-Pierce, M. (2012), Symbolic Power in the World Trade Organization, Oxford: Oxford University Press.

Friedman, E. J., K. Hochstetler, and A.-M. Clark (2005), Sovereignty, Democracy, and Global Civil Society: State-Society Relations at UN World Conferences, Albany: SUNY Press.

Georgiev, D. and K. Van der Borght (eds.) (2006) Reform and Development of the World Trade Organization Dispute Settlement System, Cambridge: Cameron May.

Hannah, E. (2014), 'The Quest for Accountable Governance: Embedded NGOs and Demand-Driven Advocacy in the International Trade Regime', Journal of World Trade, 48(3): 457-479.

— (2016), NGOs and Global Trade: Non-State Voices in EU Trade Policymaking, Abingdon: Routledge.

Hannah, E., Scott, J. and Trommer, S. (eds) (2015), Expert Knowledge in Global Trade, Abingdon and New York: Routledge.

He, B. and H. Murphy (2007), 'Global Social Justice at the WTO? The Role of NGOs in Constructing Global Social Contracts', International Affairs, 83(4): 707-727.

Higgott, R. and E. Erman (2010), 'Deliberative Global Governance and the Question of Legitimacy: What Can We Learn from the WTO?', Review of International Studies, 36(2): 449-470. 
Hoekman, B. (2012), 'Proposals for WTO Reform: A Synthesis and Assessment', in M. Danton, A. Narlikar, and R. M. Stern (eds.), The Oxford Handbook on the World Trade Organization, Oxford: Oxford University Press, pp. 743-775.

Hopewell, K. (2015), 'Multilateral Trade Governance as Social Field: Global Civil Society and the WTO', Review of International Political Economy, 22(6): 1128-1158.

- (2016), 'Invisible Barricades: Civil Society and the Discourse of the WTO', Globalizations, online first, http:/dx.doi.org/10.1080/14747731.2016.1162984.

Howse, R. (2002), 'From Politics to Technocracy - and Back Again: The Fate of the Multilateral Trading Regime', American Journal of International Law, 96(94): 94-117.

Marceau, G. (ed.) (2015), A History of Law and Lawyers in the GATT/WTO: The Development of the Rule of Law in the Multilateral Trading System, Cambridge: Cambridge University Press.

Meléndez-Ortiz, R., C. Bellman, and M. R. Mendoza (2012), The Future and the WTO: Confronting the Challenges, Geneva: ICTSD.

Pianta, M. (2014), 'Slowing Trade: Global Activism against Trade Liberalization', Global Policy, 5(2): 214-221.

Piewitt, M. (2010), 'Participatory Governance in the WTO: How Inclusive Is Global Civil Society?', Journal of World Trade, 44(2): 467-488.

Scholte, J. A. (2012), 'A More Inclusive Global Governance? The IMF and Civil Society in Africa', Global Governance, 18(2): 185-206.

Scholte, J. A., R. O’Brien, and M. Williams (1998), 'The WTO and Civil Society', Centre for the Study of Globalisation and Regionalisation Working Paper No. 14/98, University of Warwick, Warwick.

Scott, J. and R. Wilkinson (2010), 'What Happened to Doha in Geneva? Re-Engineering the WTO's Image while Missing Key Opportunities', European Journal of Development Research, 22(2): 141-153.

Steffek, J. and U. Ehling (2008), 'Civil Society Participation at the Margins: The Case of the WTO', in J. Steffek, C. Kissling, and P. Nanz (eds.), Civil Society Participation in European and Global Governance: A Cure for the Democratic Deficit? Basingstoke: Palgrave, pp. 95-115

Steger, D. P. (ed.) (2009), Redesigning the World Trade Organization for the Twenty-First Century, Ottawa: Wilfrid Laurier University Press.

Tandon, Y. (2015), Trade is War: The West's War against the World, OR Books.

Warwick Commission (2007), The Multilateral Trade Regime: Which Way Forward?, Coventry: University of Warwick.

Wilkinson, R. (2003), 'ACUNS in Cancun', ACUNS Informational Memorandum, 57: 6-8, http://acuns. org/wp-content/uploads/2012/05/Fall_2003.pdf.

(2005), 'Managing Global Civil Society: The WTO's Engagement with NGOs', in R. D. Germain and M. Kenny (eds.), The Idea of Global Civil Society: Politics and Ethics in a Globalizing Era, Abingdon and New York: Routledge, pp. 160-178.

- (2006), 'The WTO in Hong Kong: What It Really Means for the Doha Development Agenda', New Political Economy, 11(2): 291-303.

- (2014), What's Wrong with the WTO and How to Fix It, Cambridge, MA: Polity.

Wilkinson, R., E. Hannah, and J. Scott (2016), 'The WTO in Nairobi: The Demise of the Doha Development Agenda and the Future of the Multilateral Trading System', Global Policy, 7(2): 247-255.

Williams, M. (2011), 'Civil Society and the WTO: Contesting Accountability', in J. A. Scholte (ed.), Building Global Democracy: Civil Society and Accountable Global Governance, Cambridge: Cambridge University Press, pp. 105-127.

Woll, C. (2013), 'Global Companies as Agenda Setters in the World Trade Organization'. in J. Mikler (ed.), The Handbook of Global Companies, Oxford: Wiley-Blackwell, pp. 257-271.

WTO (no date), '10 Things the WTO Can Do', www.wto.org/english/res_e/publications_e/wtocan_e.pdf (accessed 28 October 2015).

_ (1996), 'Guidelines for Arrangements on Relations with Non-Governmental Organizations', 23 July 1996, WT/L/162.

_ (1999), '10 Common Misunderstandings about the WTO', http://www.iatp.org/files/10_Common_ Misunderstandings_About_the_WTO.htm (accessed 28 October 2015). 
_ (2012), 'Lamy: "Multilateralism is Struggling”, opening speech at 2012 Public Forum, 24 September, www.wto.org/english/news_e/sppl_e/sppl244_e.htm (accessed 9 May 2016).

— (2013), WTO at the Crossroads: A Report on the Imperative of a WTO Reform Agenda, Geneva: WTO.

_ (2014), 'Azevêdo Highlights Trade Role in Realizing Africa's "Sheer Potential”, opening speech at 2014 Public Forum, 2 October, www.wto.org/english/news_e/spra_e/spra35_e.htm (accessed 9 May 2016). 